\title{
Assessment of Coal Geology, Resources, and Reserve Base in the Powder River Basin, Wyoming and Montana
}

Using a geology-based assessment methodology, the U.S. Geological Survey estimated in-place resources of 1.07 trillion short tons of coal in the Powder River Basin, Wyoming and Montana. Of that total, with a maximum stripping ratio of 10:1, recoverable coal was 162 billion tons. The estimate of economically recoverable resources was 25 billion tons.

\section{Introduction}

The U.S. Geological Survey (USGS) is responsible for providing objective scientific information to support decisions regarding land management, environmental quality, and economic, energy, and strategic policy. To accomplish this goal, the USGS periodically assesses the Nation's endowment of various energy resources, including coal. Because the amount of economically recoverable coal resource is substantially less than the total original volume of coal in place, coal reserve base estimates provide essential information for energy-related decisions (Luppens and others, 2009). To be classified as "reserves," the coal must be considered economically producible at the time of classification.

Regional-scale reserve estimates are based on prefeasibility scoping-level studies in turn based on conceptual mine designs. Prefeasibility studies have a higher degree of uncertainty than feasibility studies developed for commercialization of a specific property. Conceptual mine designs do not have sufficient detail to support a final decision by a financial institution to support development of a coal deposit to the production stage.

The goal of the current USGS United States Coal Resources and Reserves Assessment Project is to conduct regional-scale, coal resource and reserve assessments of the significant coal beds in all major U.S. coal basins. The Powder River Basin (PRB) in northeastern Wyoming and southeastern Montana (fig. 1) was the first basin to be assessed under this effort. It contains the largest deposits of low-sulfur subbituminous coal in the world. In 2011, coal production from 16 mines in the basin totaled 462 million short tons (MST), some 42 percent of the total coal production in the United States, making the PRB the single most important coal-producing basin in the Nation. About 426 MST (92 percent of total PRB coal production) came from the Gillette coal field, which is located along the eastern margin of the Wyoming PRB (fig. 1). The results presented here update coal resource and reserve estimates for the PRB and represent the first completed regional-scale assessment intended to revise the Nation's coal reserve base.

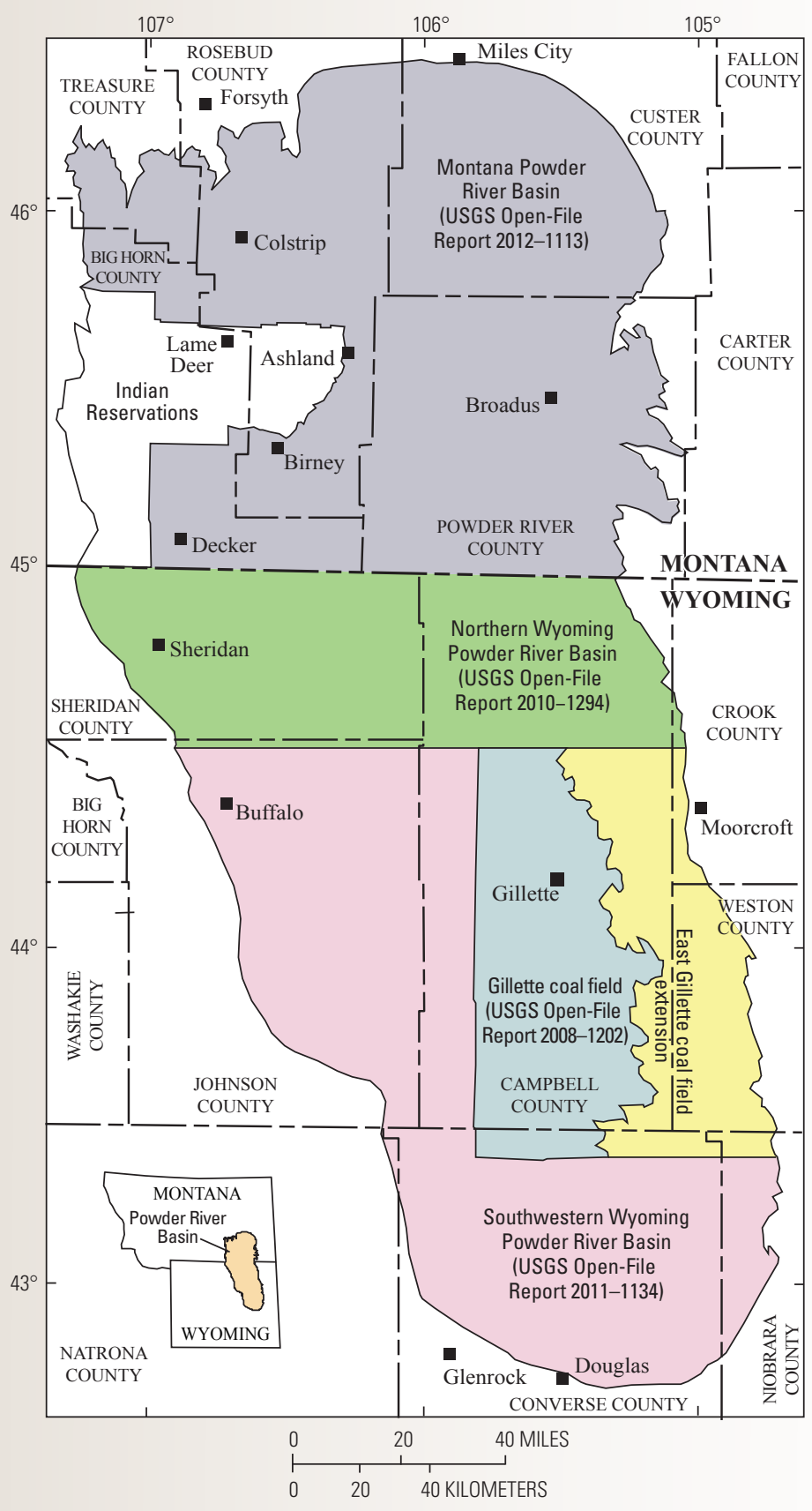

Figure 1. Location of individual coal assessment areas in the Powder River Basin, Wyoming and Montana. From Haacke and others (2013). 
The Powder River Basin, an elongate, north-northwesttrending basin, covers about 19,500 $\mathrm{mi}^{2}$ (see fig. 1), exclusive of the part of the basin within the Crow and Northern Cheyenne Indian Reservations in Montana. The PRB forms a broad asymmetric syncline with gentle westward dips along the eastern flank and steep eastward dips along the western flank. The synclinal axis lies nearer the basin's western margin, trending north-northwest in the Wyoming part of the PRB and gradually turning northnortheasterly in the Montana part (fig. 2). Because the coal beds are thick, shallow, and gently dipping along the eastern margin of the Wyoming part of the basin, large open-pit mines have been developed there to extract near-surface coal resources (fig. 3).

Four assessment subdivisions in the Powder River Basin are based on geography, geology, mining conditions, and topography, which resulted in differences in the sizes of databases among these areas and facilitated a more timely release of assessment results. The four assessed areas (fig. 1) were the Gillette coal field, Wyoming (Luppens and others, 2008); the Northern Wyoming Powder River Basin (Scott and others, 2010); the Southwestern Wyoming Powder River Basin (Osmonson and others, 2011); and the Montana Powder River Basin (Haacke and others, 2013).

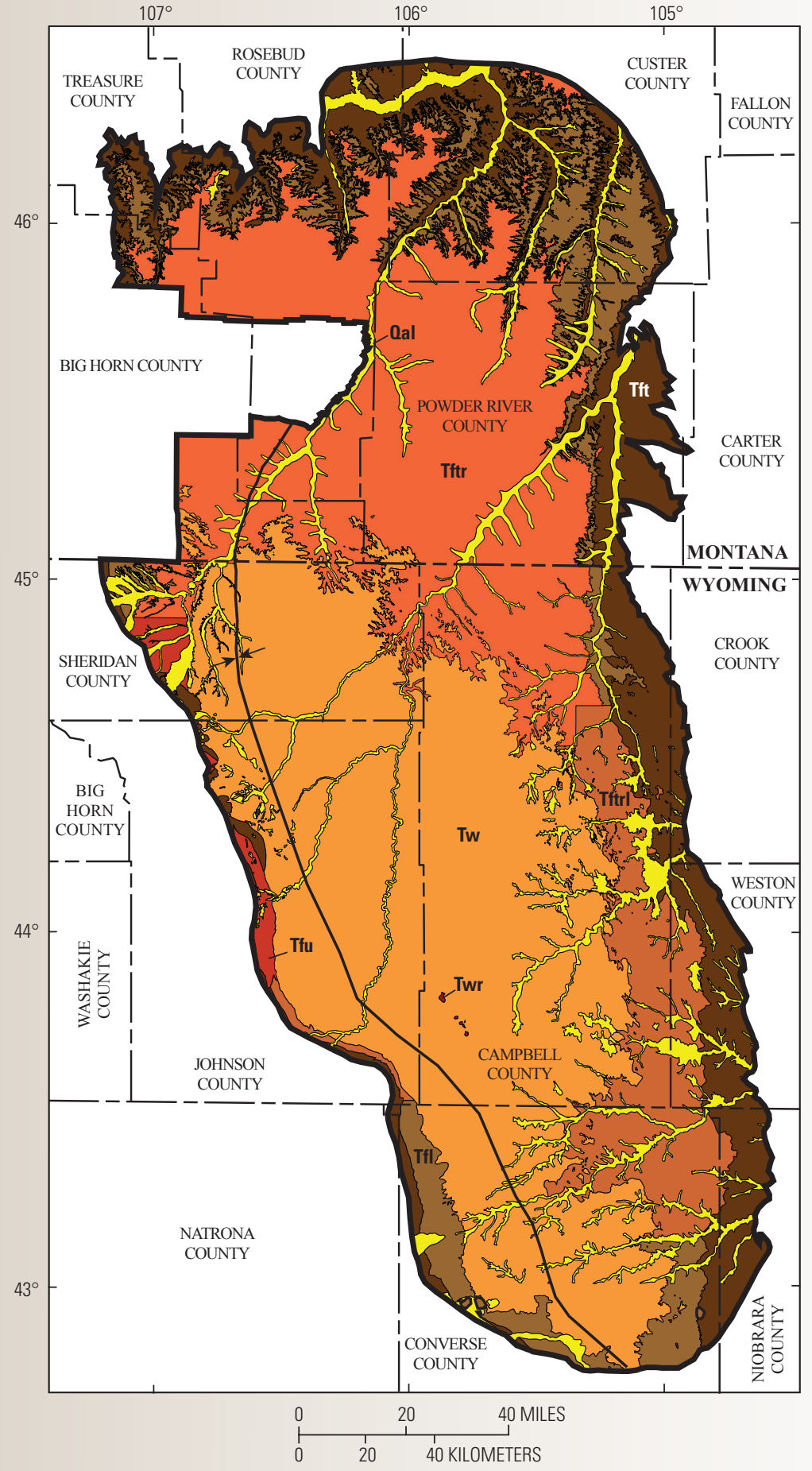

\section{EXPLANATION}

Oal Quaternary alluvium and terrace deposits Tertiary White River Formation

Tw Tertiary Wasatch Formation Tertiary Fort Union Formation (undifferentiated)

Tftr Tongue River Member

Tftrl Tongue River and Lebo Shale Members

Tfl Lebo Shale Member

Tft Tullock Member

Basin axis

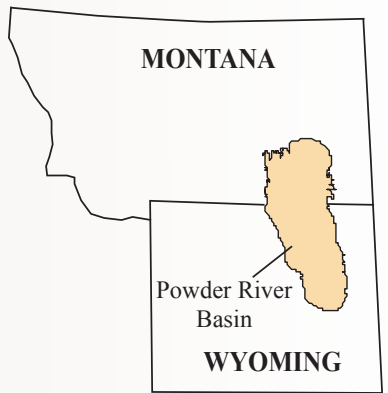

Figure 2. Generalized geology of the Powder River Basin, Wyoming and Montana. Modified from Flores and Bader (1999).

The primary objectives of the PRB assessment were to:

- Improve geological assurance by updating the stratigraphic database using information obtained from recently completed coal bed methane (CBM) and oil and gas wells;

- Develop more-comprehensive in-place coal resource computer models that also support regional reserve base estimates; and

- Complete a surface-mining economic evaluation customized to the environmental and technological restrictions of each assessed area and thereby derive regional estimates of the coal reserve base. 


\section{Study Methodology}

Earlier assessments of the Powder River Basin were based on correlations of coal zones, which included stratigraphic intervals that were as much as $800 \mathrm{ft}$ thick and included as many as six or more beds with combined coal thickness of $100 \mathrm{ft}$ or more (Flores, 1999). To evaluate mining economics, assessment of economically recoverable resources must be based on the thickness and extent of individual coal beds. The tremendous growth of CBM well development in the PRB has facilitated a unique view of subsurface geology. With completion of more than 25,000 drill holes, including corresponding geophysical logs which facilitate coal bed correlations, coal beds have been more accurately defined and correlated. For the Gillette coal field assessment alone, approximately 8,000 new drill holes were added to the geologic database for a total of 10,210 data points. Interpretation of these new data provided an unprecedented assessment of the coal resources and the reserve base in the PRB. A total of 29,928 drill holes (of which 21,393 holes were non-proprietary) were used in the overall PRB assessment (Haacke and Scott, 2013).

The assessment consisted of three phases, with the first being data collection, editing, and correlation of individual coal beds. Both the Wyoming State Geological Survey and the Montana Bureau of Mines and Geology facilitated data acquisition. The second phase involved modeling the coal beds using a digital multibed geologic modeling program to generate coal isopach, structure, and overburden maps for each assessed coal bed. Separate models were generated for the resource and reserve base evaluations using minimum coal thicknesses of $2.5 \mathrm{ft}$ and $5.0 \mathrm{ft}$, respectively. To calculate unrestricted coal resources potentially available for mining, the coal data were imported into a Geographic Information System (GIS) in which coal resources affected by mining restrictions were subtracted from the resource base. Mining restrictions included towns, railroads, environmentally sensitive areas, and coal too thin or too deep to mine economically.

The last assessment phase was a prefeasibility-level economic mining evaluation ( \pm 25 percent) to determine economically recoverable coal resources (the reserve base). Ten hypothetical mine
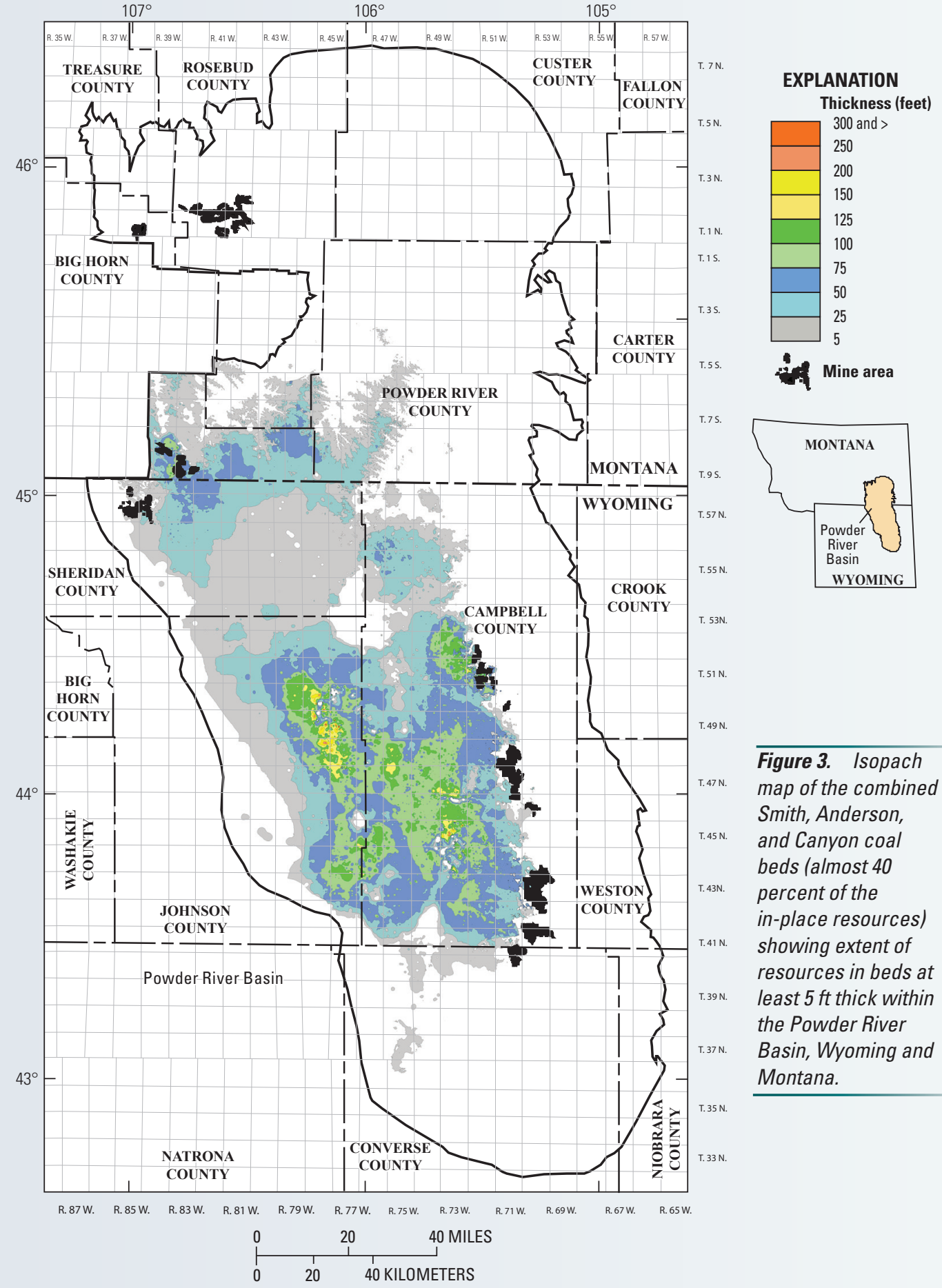

\begin{tabular}{l}
\hline Figure 3. Isopach \\
map of the combined \\
Smith, Anderson, \\
and Canyon coal \\
beds (almost 40 \\
percent of the \\
in-place resources) \\
showing extent of \\
resources in beds at \\
least 5 ft thick within \\
the Powder River \\
Basin, Wyoming and \\
Montana.
\end{tabular}

models were created, one for each stripping ratio (thickness of overburden to total thickness of coal) from 1:1 to 10:1. Geologic and mining conditions for each assessment area were used to customize the mine size and costing, and a discounted cash flow (DCF) analysis at a given rate of return (ROR) was used. Finally, GIS programs were used to calculate the volume of available coal for each of the 10 stripping ratios.
Once the available resource volumes and estimated cost to mine by stripping-ratio interval were completed, a cost curve was generated relating sales price to resources (fig. 4). The amount of coal at or below the current sales price was designated as "reserve base." The cost curve for the Gillette coal field demonstrates that a reserve base estimate is not a single value and that the amount of reserve base fluctuates as changes occur in the market price. 


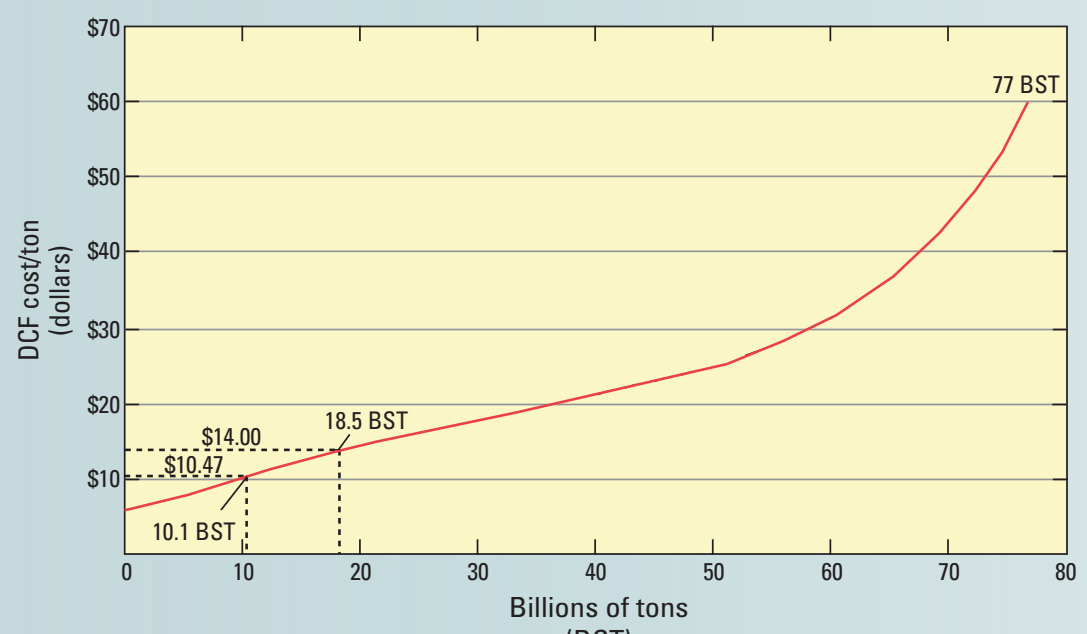

(BST)

Figure 4. Cost curve showing reserve estimates at \$10.47/ton (as of January 2007) and $\$ 14.00 /$ ton (as of March 2008) for the Gillette coal field, Powder River Basin, Wyoming (Luppens and others, 2008). [Abbreviation: DCF, discounted cash flow]

\section{Resource Assessment Results}

Based on methodology outlined above, the USGS assessed coal resources for 47 coal beds in the Powder River Basin. The most significant coal resources lie within the Roland (Baker), Smith, Anderson, Dietz 3, Canyon, Lower Canyon, Werner/Cook, Otter, Gates/Wall, and Rosebud/Knobloch coal beds of the Tongue River Member of the Paleocene Fort Union Formation. Although there are seven coal beds in the Eocene Wasatch Formation, they are of minor importance in terms of recoverable coal. These beds generally are thinner and of poorer quality than beds in the Fort Union Formation.

The USGS calculated an original in-place coal resource of 1.07 trillion short tons (TST) for the 47 coal beds in the PRB, with just ten individual coal beds representing more than 75 percent (fig. 5) of the total resources (816 billion short tons, BST). Three cross sections (figs. 6-8) and one combined isopach map of the Canyon, Anderson, and Smith beds from the Wyodak coal zone (fig. 3) display coal bed geometry in the PRB. Figure 6 illustrates the structural asymmetry of the basin whereas figure 7 shows that nearly all of the thick, shallow coal beds on the eastern side of the basin are thinner toward the southwestern side of the basin. Figure 8 illustrates the thinning and splitting of beds within the Wyodak-Anderson coal from the Gillette coal field northward into Montana. The combined isopach of the three most prominent coal beds (that is, Smith, Anderson, and Canyon; fig. 3) shows how these beds have influenced coal development in the PRB. Essentially all of the significant mining to date in the PRB is limited to shallow depths of these thick coal beds, with the exception of the Rosebud-Knobloch and Flowers-Goodale coal beds, which are mined in the northern part of the Montana PRB (fig. 3 and fig. 8).

Not all coal beds were included in evaluating mining economics for each assessment area. Only those beds with substantial areal extent, exceeding $5 \mathrm{ft}$ in thickness, and with stripping ratios less than 10:1 were included. A summary of reserve base assessments for the PRB is shown in table 1. An estimated total of 25 billion short tons of coal resources met the definition of economically recoverable resources (the reserve base). Most of the beds assessed for recoverable resources were those with in-place resources of $50 \mathrm{BST}$ or more (fig. 5).

That $25 \mathrm{BST}$ of coal resources classified as the reserve base, however, does not mean that the total amount of coal left in the Powder River Basin could be produced by surface mining technologies. Mining costs and coal sales prices are not static, as both tend to increase over time. If market prices exceed mining costs, the reserve base will grow (the converse is also true). For example, coal being mined today would not have been classified as reserve base in 1990. The cost curve from the Gillette coal field assessment (fig. 4) illustrates the dynamic nature of reserve assessments. For example, a sales price increase of only $\$ 3.43$ per ton nearly doubled the estimate of the reserve base.

For longer-term energy planning, total estimated recoverable resources of $162 \mathrm{BST}$ (table 1) represent a more important value than current reserve base estimates. In 1990, for example, resources with a stripping ratio greater than 2:1 were not classified as reserve base. Yet today, coal being mined at stripping ratios of $3: 1$ to $4: 1$ obviously now would be classified as reserve base.

There are no current underground mining operations in the Powder River Basin, nor are any anticipated in the foreseeable future. There is a significant deep coal resource base in the basin, however, and preliminary assessments of deep coal with thicknesses amenable for longwall mining were completed for the Southwestern Wyoming Powder River Basin (Osmonson and others, 2011), the northern Wyoming PRB (Scott and others, 2010), and the Montana PRB (Haacke and others, 2013). The combined underground resource for those three areas, in beds 10-20 $\mathrm{ft}$ thick (the optimal mining height for longwall mining systems), was estimated at 302 BST.

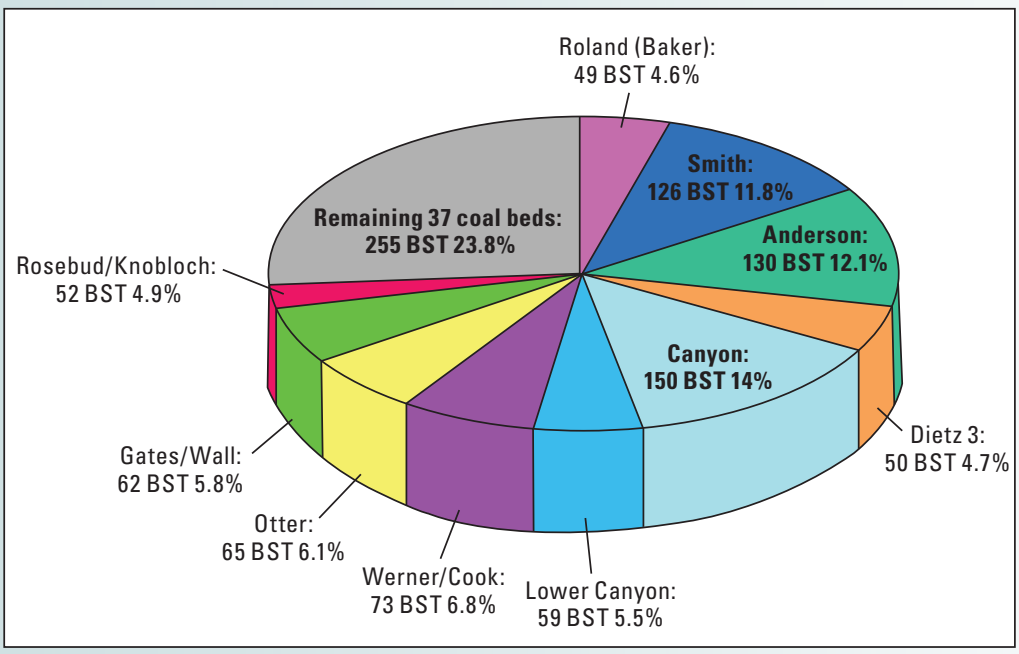

Figure 5. Pie diagram showing percentages and tonnages of individual coal beds in relation to the total 1.1 trillion short tons of coal resources in the Powder River Basin, Wyoming and Montana. [Abbreviation: BST, billion short tons; \%, percent] 

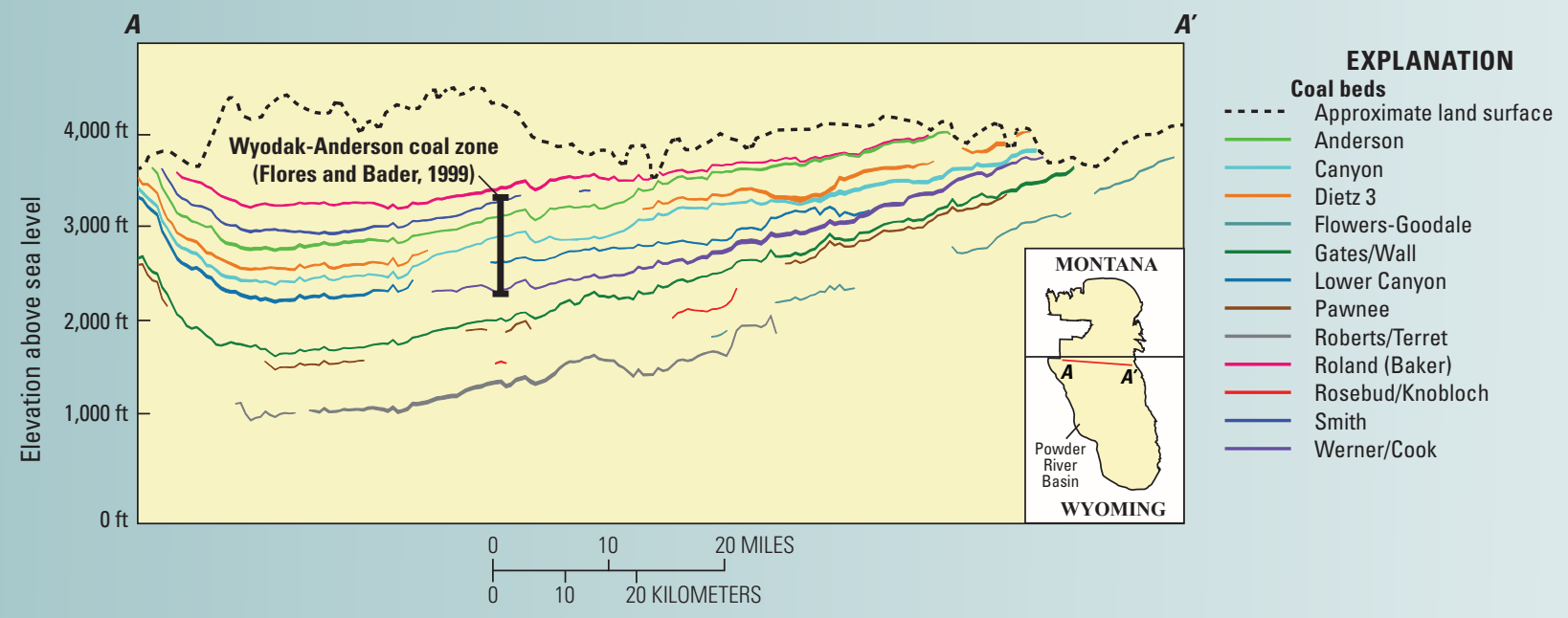

Figure 6. West-east cross section A-A' showing subsurface distribution of coal beds through the central part of the Powder River Basin, Wyoming and Montana. (Beds dip steeply along the western margin of the basin in contrast to gently dipping beds along the eastern margin.)

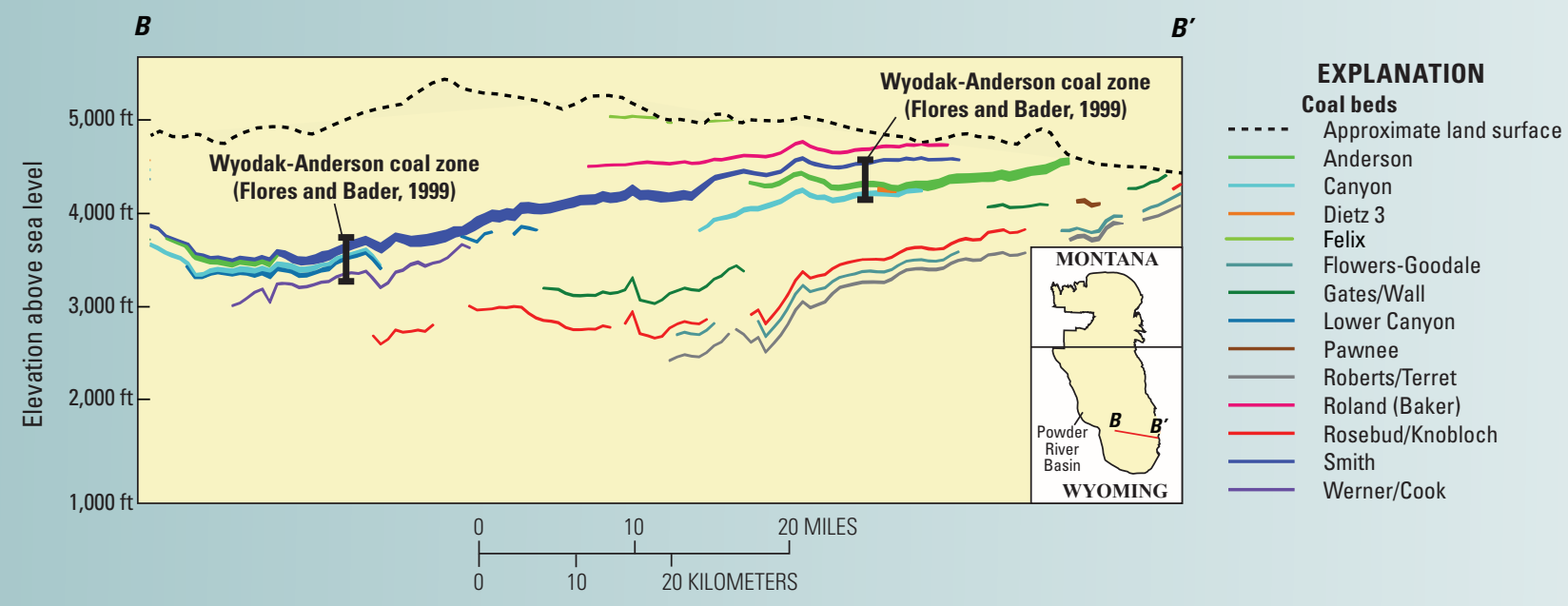

Figure 7. West - east cross section B-B' showing subsurface distribution of coal beds through the southern part of the Powder River Basin, Wyoming and Montana. (Beds dip more steeply along the western margin of the basin in contrast to gently dipping beds along the eastern margin.)

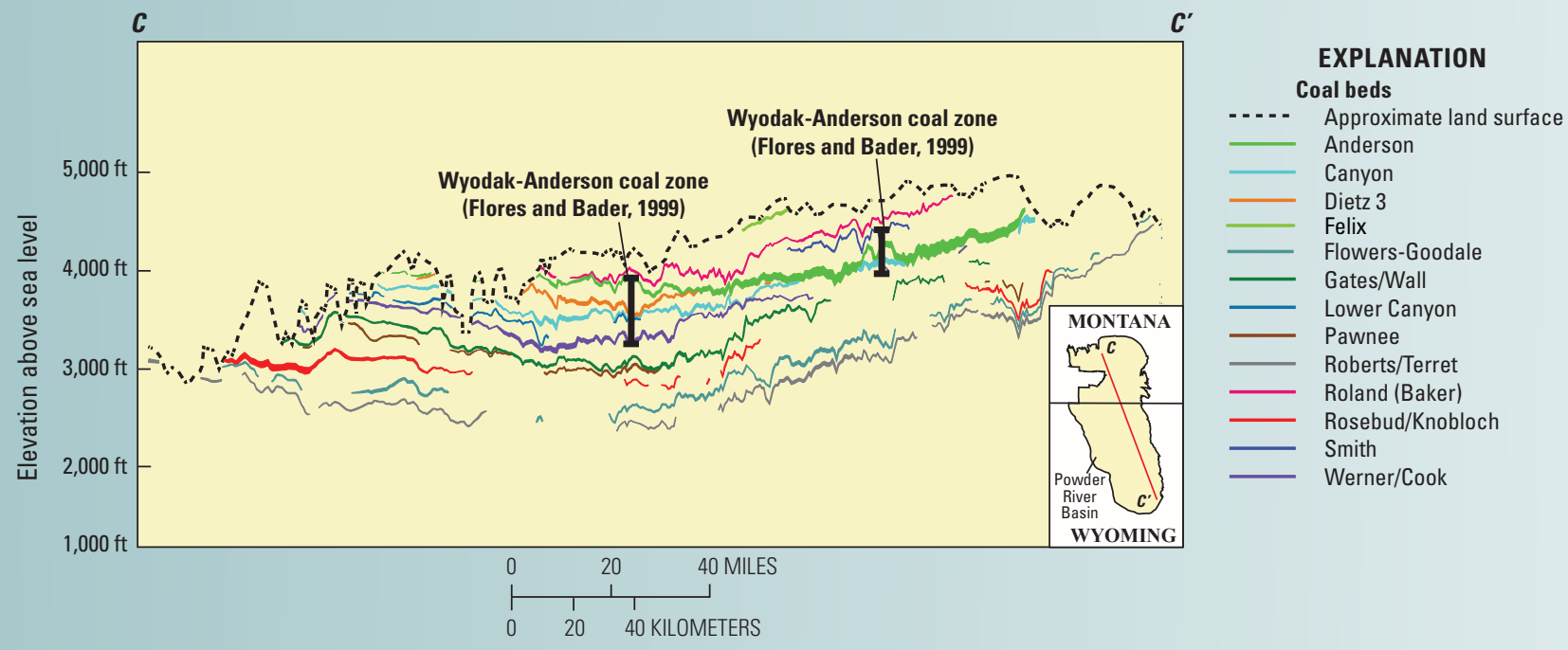

Figure 8. North — south cross section C — C' showing subsurface distribution of coal beds through the central part of the Powder River Basin, Wyoming and Montana. 
Table 1. Powder River Basin coal resources and reserve base, Wyoming and Montana, reported by assessment area, including Gillette coal field, Wyoming; NWPRB (Northern Wyoming Powder River Basin); SWPRB (Southwestern Wyoming Powder River Basin); MTPRB (Montana Powder River Basin); and PRB (Powder River Basin). (Amounts reported in billions of short tons.)

\begin{tabular}{|c|c|c|c|c|c|}
\hline & Gillette coal field & NWPRB & SWPRB & MTPRB & PRB \\
\hline $\begin{array}{l}\text { Coal beds assessed } \\
\text { for reserve base }\end{array}$ & $\begin{array}{l}\text { Roland (Baker), } \\
\text { Smith, Anderson } \\
\text { Rider, Anderson, } \\
\text { Dietz 3, Canyon }\end{array}$ & $\begin{array}{c}\text { Roland (Baker), } \\
\text { Smith, Anderson, Dietz 3, } \\
\text { Canyon, Lower Canyon, } \\
\text { Werner/Cook }\end{array}$ & & $\begin{array}{l}\text { Roland (Baker), Smith, } \\
\text { Anderson, Dietz 2, } \\
\text { Dietz 3, Canyon, } \\
\text { Rosebud/Knobloch, } \\
\text { Flowers-Goodale }\end{array}$ & $\begin{array}{c}\text { Roland (Baker), Smith, } \\
\text { Anderson Rider, Anderson, } \\
\text { Dietz 2, Dietz 3, Canyon, } \\
\text { Lower Canyon, Werner/Cook, } \\
\text { Rosebud/Knobloch, } \\
\text { Flowers-Goodale }\end{array}$ \\
\hline Total resources & 201 & 285 & 369 & 215 & 1,070 \\
\hline Total Economic Evaluation & 165 & 158 & & 165 & 488 \\
\hline Recoverable & 77 & 50 & & 35 & 162 \\
\hline Economic & 10 & 2 & & 13 & 25 \\
\hline
\end{tabular}

\section{References Cited}

Flores, R.M., 1999, Database creation and resource evaluation methodology, chap. DB of Fort Union Coal Assessment Team, 1999 Resource assessment of selected Tertiary coal beds and zones in the Northern Rocky Mountains and Great Plains Region: U.S. Geological Survey Professional Paper 1625-A, 2 CD-ROMs.

Flores, R.M., and Bader, L.R., 1999, Fort Union coal in the Powder River Basin, Wyoming and Montana-A synthesis, chap. PS of Fort Union Coal Assessment Team, 1999 Resource assessment of selected Tertiary coal beds and zones in the Northern Rocky Mountains and Great Plains Region: U.S. Geological Survey Professional Paper 1625-A, 2 CD-ROMs.

Haacke, J.E., Scott, D.C., Osmonson, L.M., Luppens, J.A., Gunderson, J.A., and Pierce, P.E., 2013, Coal geology and assessment of coal resources and reserves in the Montana Powder River Basin: U.S. Geological Survey Open-File Report 2012-1113, 133 p.

Haacke, J.E., and Scott, D.C., 2013, Drillhole data for coal beds in the Powder River Basin, Montana and Wyoming: U.S. Geological Survey Data Series DS 713, 15 p.

Luppens, J.A., Scott, D.C., Haacke, J.E., Osmonson, L.M., Rohrbacher, T.J., and Ellis, M.S., 2008, Assessment of coal geology, resources, and reserve base in the Gillette coal field, Powder River Basin, Wyoming: U.S. Geological Survey Open-File Report 2008-1202, 127 p.

Luppens, J.A., Rohrbacher, T.J., Osmonson, L.M., and Carter, M.D., 2009, Coal resource availability, recoverability, and economic evaluations in the United States-A summary, chap. D of Pierce, B.S., and Dennen, K.O., eds., The national coal resource assessment overview: U.S. Geological Survey Professional Paper 1625-F, 17 p.

Osmonson, L.M., Scott, D.C., Haacke, J.E., Luppens, J.A., and Pierce, P.E., 2011, Assessment of coal geology, resources, and reserve base in the Southwestern Powder River Basin, Wyoming: U.S. Geological Survey Open-File Report 2011-1134, 135 p.

Scott, D.C., Haacke, J.E., Osmonson, L.M., Luppens, J.A., Pierce, P.E., and Rohrbacher, T.J., 2010, Assessment of coal geology, resources, and reserve base in the Northern Powder River Basin, Wyoming: U.S. Geological Survey Open-File Report 2010-1294, 136 p.

View of a surface coal mine in the Powder River Basin near the town of Gillette, northeastern Wyoming. Photograph by J.A. Luppens, U.S. Geological Survey.

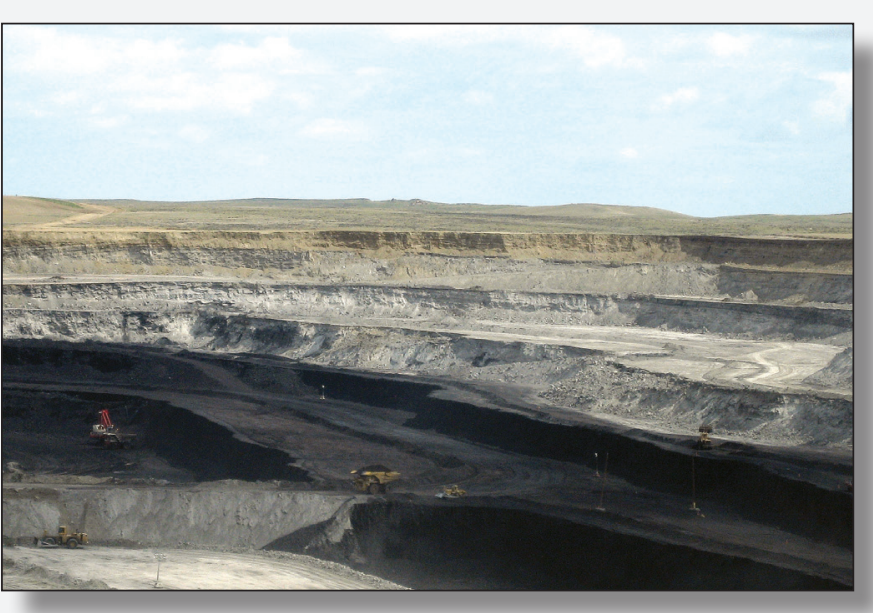

For Further Information

Coal Assessment Team

Contact Information
Supporting assessment reports are available at the USGS Energy program website, at http://energy.usgs.gov.

James A. Luppens, David C. Scott, Lee M. Osmonson, Jon E. Haacke, and Paul E. Pierce.

James A. Luppens (jluppens@usgs.gov) David C. Scott (dscott@usgs.gov) 